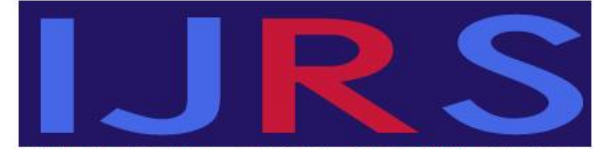

- INTERNATIONAL JOURNAL OF ROMA STUDIES .
Hipatia Press

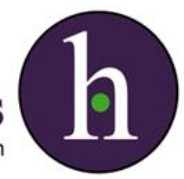

Instructions for authors, subscriptions and further details:

http://ijrs.hipatiapress.com

\title{
Contributions of Brazilian Educational Policies: Possibilities of Dialogue and Appreciation of Ethnic and Racial Diversity in the School Context
}

Marciele Nazaré Coelho ${ }^{1}$, and Francisca de Lima Constantino²

1) Instituto Superior de Ciências Sociais e Relações Internacionais (CIS). Angola

2) Universidade Federal de São Carlos - Núcleo de Investigação e Ação Social e Educativa (NIASE). Brazil

Date of publication: March $15^{\text {th }}, 2020$

Edition period: March 2020 - September 2020

To cite this article: Nazaré Coelho, M., and de Lima Constantino, F. (2020). Contributions of Brazilian Educational Policies: Possibilities of Dialogue and Appreciation of Ethnic and Racial Diversity in the School Context. International Journal of Roma Studies, 2(1), 41-63. doi: 10.17583/ijrs.2020.5120

To link this article: http://dx.doi.org/10.17583/ijrs.2020.5120

PLEASE SCROLL DOWN FOR ARTICLE

The terms and conditions of use are related to the Open Journal System and to Creative Commons Attribution License (CCAL). 


\section{Contributions of Brazilian}

\section{Educational Policies: Possibilities of}

Dialogue and Appreciation of

Ethnic and Racial Diversity in the

School Context

Marciele Nazaré Coelho

CIS. Angola
Francisca de Lima Constantino

NIASE. Brazil

\section{Abstract}

The diversity of cultures, that is, the ways of being and acting in the world, is a concept increasingly present in schools, especially in classrooms. Immigration, internal and external displacement, and different cultures and ethnicities existing in schools imply reflections of an emancipatory, dialogical education that demands teachers and students to take a stance and support a dialogue favoring the unity in diversity and equality of differences. With this in view, we dedicate ourselves to the dualistic and emancipatory theories that can contribute to the reflection of events occurring in the educational context. From the aspect of communicative methodology, the analysis of educational practices, based on segments of previous field research, brings to the dialogue the possibilities schools obtain by working with the Brazilian legislation in the scope of the black Afro-Brazilian and African culture. Based on the results, we present the possibilities of an antiracist education favoring dialogue and respect between students from various backgrounds.

Keywords: educational policies, transformation, diversity, equality of differences

2020 Hipatia Press

ISSN: $2462-425 \mathrm{X}$

DOI: $10.17583 / \mathrm{ijrs} .2020 .5120$
Hipatia Press

www.hipatiapress.com

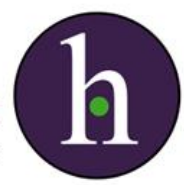




\section{Contribuciones de las políticas educacionales brasileñas: posibilidades para el diálogo y la valorización de la diversidad étnica y racial en el contexto escolar}

Marciele Nazaré Coelho

CIS. Angola
Francisca de Lima Constantino NIASE. Brazil

\section{Resumen}

La diversidad de culturas, de las formas de ser y de estar en el mundo, se impone cada vez más como un proceso presente en el contexto de las escuelas y de manera especial en las aulas. La inmigración, los desplazamientos internos y externos, las diferentes culturas, las etnias presentes en la escuela implican en reflexiones de una educación emancipadora, dialógica que exige de profesores, profesoras, alumnos y alumnas un posicionamiento y un diálogo a favor de la unidad en la diversidad y a favor de la igualdad de diferencias. En esta perspectiva, nos dedicamos a las teorías duales y emancipadoras que pueden contribuir a la reflexión de los acontecimientos que tuvieron lugar en el contexto educativo. Fundamentadas en la metodología comunicativa, el análisis de prácticas educativas, a partir de un recorte de investigación de campo ya finalizada, trae para el diálogo las posibilidades que la escuela tiene en el trabajo con la legislación brasileña en el ámbito de la cultura negra, afrobrasileña y africana. Fundamentados en los resultados, presentamos las posibilidades de una educación antirracista que favorezca el diálogo y el respeto entre los diferentes.

Palabras clave: políticas educativas, transformación, diversidad, igualdad de diferencias 

T he general objective of this article is to discuss a more specific context of classroom didactics - that is, the classroom event in educational context - from the perspective of educational policies aimed at diversity. What we term here a classroom event is what is produced and experienced in the school space within the scope of cultural and ethnic diversity. The specific objectives of this article are to contribute to dualistic and emancipatory theories in the scope of equality of differences and interculturality, to historically classify Brazilian educational diversity policies, and to present the transformative and exclusionary dimensions from the dialogue between black and white teachers based on practices aimed at interculturality and equality of differences in three Brazilian public schools.

The school space is multifaceted. It is a diverse space where we find both the legal citizens and foreign nationals due to increased immigration and forced displacements, as is the case of refugees, and migrant nationals in search of better living conditions displaced within a country. We further identify the African presence in Brazil and the Romany presence in Spain, among other peoples who move, communicate, and build their histories. Thus, the diversity of ethnicities, peoples, languages, and cultures in schools is growing. Such a scenario raises questions in education, instigating the debate about the role the schools will play, the kind of education, and how the teaching and learning process will provide a space for dialogue with diversity.

Emancipatory education, within the scope of dualistic theories of understanding society considering the equality of differences and unity in diversity, points to the way of working with the possibilities presented by the legislation and educational policies in favour of diversity, which have existed in Brazil since the mid-1990s.

To better understand this investigative objective from the aspect of communicative methodological approach, we will reflect on the educational contexts, the experiences, and analysis of primary school teachers and present the possible experiences to be implemented in the school that seeks the appreciation of diversities in view of equality of differences. 


\section{Theoretical Background}

Historically, Brazil was made up of different peoples, those who arrived due to forced migration as enslaved African emigrants or in migration waves, especially from Europe and Asia. The formation of the Brazilian identity must be guided by the initial makeup of the country, that is, the identity of indigenous peoples, the blacks, and the whites. However, the concept of racial democracy in Brazil where all cultures interact harmoniously has persisted over the decades, giving an idea that all of them are part of the Brazilian identity and valued equally, contrary to reality.

In this sense, both the black and indigenous populations have had their history and culture devalued throughout Brazilian history, and their right to education has been denied for decades.

Studies on diversity, differences, and cultures in the field of education gained momentum in the 1980s, and many researchers covered issues such as ethnicity, being black, the role of black people in books and teaching materials, racism in classrooms, etc. (Munanga, 1985; Silva, 1987).

October 5, 1988, reflects a fundamental milestone - the promulgation of the Federative Constitution of Brazil, based on the rights for all, without distinction, respecting their equality before the law-marking in an expressive way the subsequent discussions on ethnic and cultural plurality.

In the 1990s and 2000s, indigenous studies in Latin America also gained prominence, with an emphasis on issues such as indigenous linguistics, identity, and culture, developing the concept of interculturality from the concepts of bilingualism and biculturalism, which later contributed to diversity studies in a broader way.

The concept of interculturality is polysemic. It is based on the concept of multiculturalism, which recognizes human diversity. In the context of conceptual differences, functional interculturality and criticism stand out. Functional or neoliberal interculturality defends the need for dialogue and recognition, but it does not relate to the growing social, economic, and rights inequalities of socially disadvantaged peoples. The concept of interculturality, in a critical view, perceives the reality of ethnicities and cultures in the dimension of their valorisation, that is, seeking the maintenance of tradition. On the other hand, it defends a critical perspective 
of identity and cultural construction as something that is not immutable, with a focus on class, economic rights, and social justice inequalities (Ruiz, 2014).

Marín (2017) points out that with the emergence of the concept of interculturality, governments have used it as a possibility of action in favour of the cultural assimilation of indigenous peoples; however, the intercultural vision has its roots in dialogue and the interaction between cultures and knowledge, which enable the respectful coexistence of all.

In view of the studies initially carried out on the racial issues, and later on the cultural, ethnic, and racial diversity, including indigenous studies subject to different theoretical approaches, we will present three fundamental perspectives that we intend to synthesize with the field of diversity-related studies.

The first perspective is based on functionalist theories, and it sees the school as a space of reproduction, where differences are denied, and equality does not exist. There is only homogenization, that is, all are and should be equal, and differences are suppressed in the name of the homogenization of different subjects. Reality is given, and social agents cannot change it. In this sense, the school context is characterized as a place of social selection and cultural reproduction of society (Coelho, 2011).

According to Coelho (2011), the second perspective, based on postmodern theories, focuses on tolerance, in which one tolerates the other respecting this difference, valuing all the individual differences and those of the group, within each group and ethnicity. In this way, it is understood that reality is constructed by the subject: It is subjective and depends on the meanings that individuals attribute to it. The school becomes the place of differences, and subjects modify reality from their conceptions about themselves and about others. However, it does not mean that there are the dialogue and coexistence between different subjects within or outside the school context.

The third perspective fits into the studies on critical social, emancipatory, and dualistic theories, which perceive the school as a space of transformation. In this sense, diversity becomes fundamental for the existence of the school and the learning of different topics, because the school context becomes dynamic, where not only the encounter of different 


\section{Nazaré C. \& de Lima C. - Brazilian Educational Policies}

cultures takes place but there is also a relationship between them and the subjects within those cultures (Coelho, 2011).

The dualistic perspective sees the school as a space of reproduction and as a space of struggle and transformation. Being a space of transformation, the school transforms cultures, ethnicities, and ways of acting and being in the world and with others. There is dialogue and interaction. In this area, there is the conceptual equality of differences.

The equality of differences presupposes that different people can live together in the same territory and with equal rights, which do not harm but strengthen their respective identities (Flecha, Gómez, \& Puigvert, 2001). The equality of differences comprises diversity in its unity:

The goal of unity in diversity implies that all people have the equal right to education, regardless of gender, class, culture, age, etc. Through diversity, a situation of equality is reached that is not homogeneous. Dialogical learning is oriented toward the equality of differences by affirming that it is possible to live together in true equality, which includes the same right of every person to live differently (Elboj \& Pérez, 2003, p. 101 - our translation).

In this sense, education is egalitarian, where everyone has the right to be different and to be respected in his or her particularity, but from the perspective of dialogue with other subjects, because different cultures live together in the same space, different subjects share this space and need to make their cultures interact through a dialogue.

The dialogue between and within cultures also makes contributions based on the concept of interculturality, a concept that is born within the discussions on indigenous diversity and contributes to the discussion of cultural, racial, and ethnic issues.

The concept of interculturality implies a relationship between cultures, that is, understanding of cultural demands requires understanding the culture of the worlds in contact (Cornejo, 2012).

From this perspective, thinking about an intercultural education means going beyond the limit of contact and encounter between cultures, peoples, and different ethnic groups and establishing a relationship of dialogue between and within different cultures, from an intercultural experience. 
"The recognition of diversity is part of multicultural education, and the dialogue and interrelationship between these diversities presuppose an intercultural education" (Coelho, 2011, p. 66).

Thus, the school as a space loaded with different forms and cultural symbolisms must also be a space of dialogue that favours the subjects that compose an egalitarian experience of their ways of acting, being, and understanding the world (Nune, 2011).

When we emphasize different ways of acting, being, and living, we are dealing with the diversity that exists within each culture, that is, the different ways of being Brazilian, Angolan, Spanish, Guinean, or Italian. This diversity is in the world, with it and within it, and for this reason, it needs to be understood within the duality in which reality and society, the school and society are inserted.

In this sense, "we stress the importance of the school being involved with the different social agents. The school is surrounded by people that compose different voices, and the dialogical relations permeate these voices, composing the various factors of society" (Silva, 2015, p. 60).

The ways of acting and being of these different voices go beyond the school space and are built in the relationships in society, in the different educational spaces; therefore, they cannot be ignored and/or silenced. As Gomes e Silva (2002) points out, the subjects have a life history, representations, experiences, identity, beliefs, values, and customs of their own that start to be a part of the educational environments where they transit with their particularities and similarities, which make up the context of diversity.

It is in this context that emancipatory education is placed, which according to Freire (2007) seeks to develop the critical, citizen conscience, in a vision of subjects' humanization.

The education that seeks to be dialogical, that seeks the dialogue of the human being with the world, with the objective of transforming it, is the education that Freire (2007) defends as a practice for freedom and emancipation that leads the subject to be in the world and with the world and not just a mere object of history.

In presenting the theoretical foundations of the dualistic perspective and emancipatory education, highlighting the topic of cultural and ethnic 


\section{Nazaré C. \& de Lima C. - Brazilian Educational Policies}

diversity in the dialogue with the concepts of interculturality and equality of differences, we take as an object of study the event in the classroom and the possibilities that this space provides for working with educational policies in favour of what is plural and diverse, that is, that seeks possibilities to become more.

\section{Educational Policies Considering Diversity and Making It Pedagogical: Alternatives for Education on Equality of Differences and Interculturality}

The diverse context of the school today, regardless of the geographic location, is a reality that needs to be considered within the possibilities presented by the educational laws and policies of every country.

In the Brazilian context, the concern with socially, culturally, and ethnically disadvantaged groups, that is, identities considered to be of lesser status, began to gain ground in discussions, research, and policies in the 1970s and 1980s, and it intensified in the 1990s. For Carvalho and Faustino (2015), educational policies to recognize and value cultural diversity will influence government actions in different countries from 2000 onward.

The Constitution of the Federative Republic of Brazil (1988) in Chapter III "Education, Culture and Sport," Section I "Education," Articles 205 and 206, defines education as a right of all and guarantees equal conditions to its access and permanence in the educational system. Article 210 of the same section, Paragraph 2, defines that teaching will be conducted in Portuguese; however, it ensures that indigenous groups will be able to use their mother tongue and also guarantees the use of their own learning processes (Brazil, 1988). In this sense, education must be built on and in favor of dialogue in diversity, based on educational experiences at school, so that it can effectively be a place of permanence with an access to multiple learning, and to contemplate different ways of acting, being, thinking, and learning that can be considered under this legislation.

In 1996, the Law of Guidelines and Bases of National Education (LDB), Law no. 9,394 of December 20, was passed, which defines the foundations of Brazilian national education, reaffirming the principles already highlighted in the Brazilian Constitution, and in its Article 26, Paragraph 4, 
it establishes that the teaching of Brazilian history must encompass different cultures and ethnicities that participated in the formation of the Brazilian people, especially those of African, indigenous, and European origin (Brazil,1996).

Still at the end of the 1990s, focused on the first grades of basic education, the National Curricular Parameters (PCNs) were elaborated and organized in nine themes, with an emphasis on the volume dedicated to the topic of cultural plurality and sexual orientation, which emphasizes the need to be a reference for the renewal and re-elaboration of curricular proposals, especially from the reformulation of the school's educational project, seeking quality improvement (Brazil, 1997).

In this period, the first concerns in the field of Brazilian educational policies for diversity can be noted. In the National Curriculum Parameters (PCNs), as highlighted above, diversity is designed as cultural plurality within one of the cross-cutting themes that curricula are called to address. However, there are no objective indications of overcoming racism and racial inequality but only a general topic (Gomes, 2010).

At the beginning of the 2000s, the Law no. 10,639/2003, that modifies the Law no. 9,394/1996, that is, LDB, in the official curriculum of the Education Network made the topic of Afro-Brazilian and African history and culture obligatory. ${ }^{1}$ This law was born as a policy of affirmative action for education in the Brazilian state and as a compensatory policy.

According to Almeida and Sanchez (2017), the rising point of Law no. $10,639 / 2003$ is the questioning of the official school curriculum; considering that the Brazilian Constitution (1988) contemplates the obligation to attend basic education, the curriculum is presented as the official route of representations that one wants to value in school.

In this context, the transformation of the school was considered from the insertion of the African and Afro-Brazilian history and culture topics in the curriculum. As Gomes and Jesus (2013) indicate:

The amendment of articles 26-A and 79-B of Law no. 9,394/96Law of Guidelines and Bases of National Education (LDB) - by Law no. 10,639/2003 (BRAZIL, 2003), the Resolution CNE/CP 1/2004, which defines the National Curricular Guidelines for the Education of Ethnic-Racial Relations and for the Teaching of 


\section{Nazaré C. \& de Lima C. - Brazilian Educational Policies}

African and Afro-Brazilian History and Culture (BRAZIL, 2004), based on the CNE/CP Decision 3/2004, compose a set of legal devices considered to be initiators of an educational policy aimed at the affirmation of cultural diversity and the achievement of education of ethnic-racial relations in schools, triggered from the 2000s (Gomes \& Jesus, 2013, p. 21 - our translation).

In this view, we rely on a legal apparatus that subsidizes the teaching practice for a more fruitful work for an education focused on equality of differences and interculturality since introducing the topic into the school and classroom contexts still causes tension, and the teacher often does not know what is the best way to problematize discussions about racial discrimination and other forms of prejudice.

In this sense, the implementation of Law no. 10,639/03 enables answers both in the educational and social spheres, since it meets "old claims of the black movement and proposes a new commitment to the teaching of Brazilian history, seeking to value and disseminate black culture as a constituent part of Brazilian culture" (Constantino, 2010, p. 90).

Law no. 10,639/03, which brings the policies in favor of work with diversity, highlights that:

signals advances in the realization of educational social rights and implies the recognition of the need to overcome illusions, social representations, and racist discourses and practices in school education. It also implies a state stance on intervention and the construction of an educational policy that takes into account diversity and opposes the presence of racism and its effects, whether it is in the broader educational policy, in the organization and operation of school education, in the curricula of initial and continuing teacher training, and in pedagogical practices and social relations at school (Gomes \& Jesus, 2013, p. 22 - our translation).

Therefore, making the law applicable in the school context means breaking the silence that permeates the school walls about the blackness, culture, and identity and thinking about daily actions, as well as considering different topics that are part of the diversity of our society. In so doing, we do not want to claim that bringing up the discussion on respect for 
differences is something easy for a society that believes in the myth of racial democracy and that sometimes denies the existence of racism in its context. However, there is a need to break the silence, and Law no. $10,639 / 03$ is a milestone in Brazilian education, representing a break from the white hegemony.

For the regulation and effective implementation of this law, according to Almeida and Sanchez (2017), we have nine educational policies that regulate it, especially the Decision of the National Education Commission No. 003 of March 10, 2004, which later regulates Resolution No. 001 of June 17, 2004, establishing the National Curriculum Guidelines for the Education of Ethnic-racial Relations and for the Teaching of African and Afro-Brazilian History and Culture, with later consolidation with the regulation of the National Plan for the Implementation of Curriculum Guidelines in 2009.

The National Plan for the Implementation of the National Curricular Guidelines for the Education of Ethnic-Racial Relations and for the Teaching of African and Afro-Brazilian History and Culture was made with the objective of institutionalizing and promoting the practice of these guidelines in educational contexts throughout Brazil (Gomes \& Jesus, 2013).

Resolution No. 001 of 2004 turns to institutions of initial and continuing teacher training, establishing the inclusion of content on ethnic and racial relations in the topics and curriculum activities in the courses they teach (Brazil, 2004).

In the area of training, Brazil presents seven policies of formative action for teachers, considered as continuing education for teachers and professionals in the school context. With regard to the materials created to implement Law no. 10,639/03, seven policies that involve the production of educational materials, projects, and the General History of Africa Collection written by authors from different countries (Almeida \& Sanchez, 2017) stand out.

In 2008, Brazil approved Law no. 11,645, which established the guidelines and foundations for national education to include the issues relating to black and indigenous peoples in the official curriculum, contributing in this sense to the further development of indigenous studies. 


\section{Nazaré C. \& de Lima C. - Brazilian Educational Policies}

Two years later, it established the Statute of Racial Equality, defined by Law no. 12,288/2010. In 2012, Law no. 12,711/2012, referred to as the Quota Law, was approved, which guarantees the reservation of vacancies for entry into higher education and, in 2014, the reservation of $20 \%$ of vacancies for blacks in public tenders to fill effective positions and public jobs in the federal administration, municipalities, public foundations, public companies, and mixed-economy companies controlled by the state (Gouvêa \& de Lima, 2016).

According to Wainer and Melguizo (2018), the approval of the Quota Law foresaw the reservation of $50 \%$ of vacancies in all graduation courses for black students and for students coming from public schools by 2016, also seeking to standardize the criteria for vacancy reservations.

The actions mentioned so far have driven the recognition of racism in the Brazilian context, demystifying the idea of racial hegemony and cordial living among different subjects, contributing to the elaboration and implementation of public policies in favor of marginalized populations (Gouvêa \& de Lima, 2016).

For a better understanding, an overview of Brazil's national education policies for diversity is presented in Table 1.

Table 1

Brazilian Legislation on the Topic of Diversity

\begin{tabular}{|c|l|l|}
\hline Year & \multicolumn{1}{|c|}{ Document } & \multicolumn{1}{c|}{ Synthesis/Highlights } \\
\hline 1988 & $\begin{array}{l}\text { Constitution of the Federative } \\
\text { Republic of Brazil }\end{array}$ & $\begin{array}{l}\text { Chapter III "Education, Culture } \\
\text { and Sport," Section I, Articles } \\
205,206, \text { and 210 }\end{array}$ \\
\hline 1996 & $\begin{array}{l}\text { Law no. 9,394 of December 20: } \\
\text { Law of Guidelines and Bases of } \\
\text { National Education }\end{array}$ & Article 26-4§ \\
\hline 1997 & National Curriculum Parameters & $\begin{array}{l}\text { Volume "Cultural Plurality and } \\
\text { Sexual Orientation" }\end{array}$ \\
\hline 2003 & Law no. 10,639/2003 of January 9 & $\begin{array}{l}\text { Obligatory teaching of African } \\
\text { and Afro-Brazilian history and } \\
\text { culture in schools }\end{array}$ \\
\hline 2004 & $\begin{array}{l}\text { National Education Council/ } \\
\text { Council Full - CNE/CP Decision }\end{array}$ & $\begin{array}{l}\text { Decision on including the national } \\
\text { curriculum guidelines for teaching }\end{array}$ \\
\hline
\end{tabular}




\begin{tabular}{|c|c|c|}
\hline & $\begin{array}{l}\text { 3/2004: Opinion of the National } \\
\text { Education Commission no. } 003 \text { of } \\
\text { March 10, } 2004 .\end{array}$ & of ethnic-racial relations \\
\hline 2004 & $\begin{array}{l}\text { Resolution National Education } \\
\text { Council/ Council Full - CNE/CP } \\
\text { 1/2004: Resolution of the } \\
\text { National Education Commission } \\
\text { no. 001 of June 17, 2004. }\end{array}$ & $\begin{array}{l}\text { Inclusion of ethnic-racial relations } \\
\text { in the topics and curriculum } \\
\text { activities of teacher-training } \\
\text { courses }\end{array}$ \\
\hline 2008 & $\begin{array}{l}\text { Law no. } 11,645 / 2008 \text { of March } \\
10: \text { Guidelines and bases of } \\
\text { national education for the } \\
\text { inclusion of issues relating to } \\
\text { black and indigenous peoples in } \\
\text { the official curriculum. }\end{array}$ & $\begin{array}{l}\text { Guidelines for the inclusion of the } \\
\text { history of black and indigenous } \\
\text { peoples in school curricula }\end{array}$ \\
\hline 2012 & $\begin{array}{l}\text { Law no. 12,711/2012 of August } \\
\text { 29: Quota Law }\end{array}$ & $\begin{array}{l}\text { Establishes the reservation of } \\
\text { vacancies for black candidates in } \\
\text { higher education }\end{array}$ \\
\hline
\end{tabular}

To advance both the discussion on this topic and the presentation of daily events in the classroom favouring actions for the work with Law no. $10,639 / 03$ in the context of basic education, we present the methodological contributions, the results and discussions in connection with the theoretical support presented, as well as the conceptual framework for the equality of differences, unity in diversity, and interculturality.

\section{Methodological Procedures}

Aiming to fulfil the research objectives - the reflection on the classroom context from the dualistic, emancipatory, and dialogic theories within the concepts of equality of differences, unity in diversity, and interculturality that compose the understanding of the experiences in school in favour of diversity and dialogue within it - we present the qualitative approach as the methodological aspect that seeks to understand reality and reflect on it.

From the theoretical aspect, we reflect on the dualistic, dialogic, and emancipatory theories to better understand the concepts of equality of differences, unity in diversity, and interculturality. 


\section{Nazaré C. \& de Lima C. - Brazilian Educational Policies}

The theoretical support will be used to discuss educational possibilities that the school presents in a dialogical way.

The dialogical methodological approach designated as communicative methodology seeks not only to understand the reality but also to transform it with the objective of education in favor of dialogue and dialogical learning, whether of contents or of ways of acting and being in school (Gómez, Latorre, Sánchez \& Flecha, 2006).

Plaja (2019) states that research seeking social transformation is oriented toward changing the reality of a particular group or society, anchored in the commitment to social justice, that is, the guarantee of social rights in defense of human rights.

As a possibility of transforming everyday reality, the communicative approach presents two dimensions: transforming and excluding dimensions. From teachers' comments, highlighting the fragments of their individual and collective perceptions, the transforming dimensions will be presented here as a possibility of transformation of the school space, in the work with African and Afro-Brazilian cultures, thus composing the data analysis. In this approach, the transformation starts from the very subjects involved in their own reality and their relationship with others through an egalitarian dialogue.

\section{Results and discussion}

Based on the conceptual framework laid out, that is, the concepts supporting the theoretical and methodological discussion of the article, we will present the events in the school space, more specifically in the classroom, as a starting point for an analysis of the possibilities of dialogue and transformation that these events favour.

Considering authors' arguments, the research presented here sought to identify the transformative and excluding dimensions in the didactic actions of black and white teachers in the early grades of public elementary schools in the city of São Carlos, São Paulo, Brazil, using the technique of the communicative group discussion in which questions generating dialogue were presented and the teachers expressed their perceptions, ideas, and assumptions on the topic. ${ }^{2}$ This was done in the context of what Gómez and 
Díez-Palomar (2009) claim to be methodologies that create mechanisms for the inclusion of subjects' voices in the research process.

The participating public schools are located in the low-class suburbs of the city of São Carlos, serving mostly black student population from lowincome families.

In relation to data analysis regarding the communicative approach, the results of the discussion groups were discussed among the participants with the aim of presenting the best argument, understanding, and transforming its reality.

\section{The Implementation of Law No. 10,639/03 and Law No. 11,645/08 in the School Daily Life}

Considering Law no. 10.639/03 and Law no. 11,645/08 that seek to regulate the teaching of history and culture of African countries and Afro-Brazilian and indigenous cultures as a public educational policy, we present the events from a public school in the low-class suburbs of a city in the countryside of the State of São Paulo, Brazil. ${ }^{3}$ This is a starting point for the construction of transformative dimensions and excluding dimensions, not only for the experience of a specific school but also for other educational contexts and themes related to the culture and identity of peoples.

According to Gomes (2010), the individual performance of teachers interested in the theme of ethnic and racial diversity is the most common action in schools. In this sense, in the Brazilian school context, even after over 15 years of the law enactment, timid work proposals tend to sensitize teachers to the topic.

We can confirm Gomes' (2010) findings using teacher Maria's report:

I was going to talk about that year, I think it was 2010, when Cassius came, that was a year that we worked intensively, but there are children that today, ... . some that were mine are with Luana, but something was lost because they are in the 4th year, right, they addressed this topic in the 1 st year. I remember they talked about Zumbi, ${ }^{4}$ they talked about Africa, they talked about African songs, about the flags, about the Portuguese-speaking countries. (Teacher Maria, black) 


\section{Nazaré C. \& de Lima C. - Brazilian Educational Policies}

As we can see from Maria's comments, which agree with what Gomes indicates as isolated practices, there is the lack of continuity in the work on Afro-Brazilian, African, and indigenous history and culture, and this element appears as excluding, because it is an obstacle to emancipatory education.

However, even though there is no continuity in the work around the appreciation of diversity and the strengthening of black identity, it is important to point out that the practices of teachers who are sensitive to the theme are of paramount importance for the construction of an antiracist education and that the school needs to commit itself so that these actions are not isolated and that they become a part of daily school life.

The existence of educational policies focused on diversity made the implementation of actions in Brazil possible. In this sense, the importance of policies aimed at ethnic, cultural, racial, and linguistic diversity is fundamental in the process of establishing the idea of social justice and rights to experience diversity, providing an intercultural dialogue between the public sphere and its materialization in the public area of the school.

Teacher Alda brings her experience from the classroom and the way in which the content was worked out beyond the walls of the school, from the perspective that the school-world relationship represents a possibility to know more.

I remember last year when we had this conversation, especially Julio, a black boy who came and said, "Yesterday," because at the time I talked about Zumbi, "teacher, that class you taught here, I told everything about it to my mother." I was amazed because he did not, . . . he didn't wait, but he already wanted to tell he heard that there was a hero who did something . . . and he went to his house, told his family, and came back very excited. (Teacher Alda, black).

Although occasional, these activities are perceived as practices that strengthen school children, not only black children but all children, as they live in the same space-world and share existing cultures and the need to have a dialogue with them. The knowledge of national or African heroes 
allows school children and other actors to understand the fragments of African and Afro-Brazilian history.

In this sense, the experiences reported are part of the transformative dimensions of the school and the classroom context.

As we can see from teachers' comments, the practice aimed at valuing diversity and respecting differences is significant for children. The opposite also has its meaning, but in a very negative way; thus, there is the importance of systematic work in the classroom and the necessity of immediate intervention in situations of discrimination and prejudice.

The data analysis shows that existing Brazilian legislation on the diversity that makes up the Brazilian identity points to paths for change in the school and places itself as a transformational dimension, as well as the pedagogical and didactic practices carried out in the classroom, which according to Gomes and Jesus (2013) represent the guarantee of educational social rights limiting racist discourses and practices. However, it poses a challenge in teacher training.

\section{Teaching Practices for Dialogue and Appreciation of Ethnic and Racial Diversity}

Teacher Luana describes teacher intervention in case of a conflict, racism, or discrimination in the classroom and the position that a teacher should assume:

It's like I say to children, we are not obliged to like everyone, we know several people, but we have to respect people for the fact that they are human beings, regardless of whether they are different from me, something like that . . . I think that in time, again, we cannot overlook, immediate action must be taken. . . we have to try to show that it was not nice and it is not nice, and the intervention must be done immediately. (Teacher Luana, black)

Luana's comments signal the need for intercultural experience in the classroom space, in which differences exist, but independent of them, there is respectful and dialogical coexistence between the subjects, based on the concept of the equality of differences, which according to Elboj, 


\section{Nazaré C. \& de Lima C. - Brazilian Educational Policies}

Puigdellívol, Soler, and Valls (2002) is based on the participation of all people in the dialogical process from all cultures and different living spaces.

From the aspect of teacher training, the fragment points to the importance of immediate intervention in case of discrimination, racism, or prejudice in the classroom.

Teacher Alda also makes a statement in this regard:

I've been talking to them a lot, even about teasing an obese person, saying, "Why did you say that?" "I'm kidding." I say, "No, you're not kidding, you was mean." (Teacher Alda, black).

Teachers' comments and intervention are understood here as transforming dimensions, because they start from situations of discrimination in relation to different ways of acting, being, and positioning oneself in the world, moving toward using such questions to provoke reflection in the group of children.

From the situation that took place in the classroom, articulating the recommendations of Decision 003/2004, Law no. 10,639/03, and Law no. $11,645 / 08$, we can highlight in the teaching of the Portuguese language, geography, and history how the differences are placed historically in the world, presenting the curriculum content, but bringing a contextualized discussion of how, in the various sciences, they could cause conflicts. For example, in the case of geography and history, it is how linguistic differences cause conflicts in a view that to be different is to be unequal or of lesser value.

From this perspective, initial and continuing teacher training focused on the theme of valuing diversity and respect for differences is of the utmost importance in the search for more egalitarian practices in the school context. Furthermore, considering the study of Brazilian Africanness, the contributions of African and indigenous peoples to the formation of society, as well as the articulation of the knowledge of different peoples in different areas of education provides an important step toward antiracist education:

I know that training doesn't cover everything, and this is a discussion that we always have, but I think we've become aware of 
some things, and we can understand the importance, ... we see how the recipe is needed, it is needed. I think about the teachers at the beginning of their careers, how important it was for me at the beginning of my career (...) you come back and talk, . . . for other contents too, that you take a course, become aware, see that it is important to work or because you don't work, that you become aware, more that you think about an activity that you develop, that you come back to talk. (Teacher Maria, black)

The highlighted segments of Maria's comments on continued training, the "recipe" for beginners and the space for dialogue, are the elements that provide a possibility for transformation, that is, a transforming dimension in the school context when considering the respect for differences. However, the lack of these elements, whether in the educational field or in public policies, is understood as an excluding element, as an obstacle to emancipatory education.

To understand educational policies as the policies of a society and for a society, and not only the policies of a state, it is necessary to seek alternatives in the implementation, construction, and reconstruction of actions within the school in search of experiences that can transform the class and school reality.

The possibility that the legislation discussed here is correlated with the work on diversity, from the perspective of equality of differences, enables more than just working with it. It enables a dialogue with and within cultures, ethnic groups, etc.

The experiences discussed in this paper, although occasional, are highlighted in Brazilian schools located in the countryside of the State of São Paulo, where teachers reflected on their working with children around the theme of ethnic, racial, and cultural diversity. Although sporadic, they have transforming dimensions that can be understood as a starting point for other ongoing and more present activities in schools and other educational contexts, considering the indigenous experience in Brazilian schools and the discussion of linguistic interculturality, the Romany experience in Spanish schools and the constitution of an intercultural identity, and the African presence in France and the conquest of rights and the experience of interculturality. 


\section{Final Considerations}

Implemented educational policies focusing on the appreciation, dialogue, and work with ethnic, racial, and cultural diversities present themselves as transforming elements of the Brazilian educational reality, and they can be considered as elements driving other educational realities.

From the presented theoretical approach and the discussions about the understanding of ethnic, cultural, and racial diversity within the framework of dualistic theories of understanding society, and the understanding of diversity and difference in the field of equality of differences and interculturality, we note the possibilities of working with the topic in the classroom owing to Law no. 10,639/03, as well as other laws that have been part of Brazilian educational policies in the past 40 years.

In addition, bibliographical works covering this topic, which have gained ground in the research on education in Brazil focused on diversity issues in recent years, are also noteworthy. In 2000, they highlighted the research on the entry and permanence of young people and adults in the university, with reference to the approval of the Quota Law, as well as in elementary and high schools, focused on the study of daily classroom practices that value identity and diversity. On the other hand, studies focused on the formation of teachers in Brazil, especially those examining the teaching of Afro-Brazilian, African, and indigenous history and culture in schools, universities, and other educational centers, are beginning to emerge (Constantino, 2014).

The importance of developing research in the field of materialization of educational practices that transform realities has become a necessity in the field of educational studies in Brazil and, certainly, in other realities.

Teachers' comments in the context of the Brazilian public school demonstrate the possibilities of work, although still within a particular view that relies on the sensitivity of teachers to racial issues.

As demonstrated by teachers' comments, it is possible to work with the theme on a daily basis, bringing it to the formal curriculum and not only in sparse interdisciplinary projects or specific projects and commemorating 
the dates of November 20, the National Black Consciousness Day, or other important dates.

The experiences on the subject of diversity, supported by the concept of the equality of differences, demonstrate practical alternatives within the field of didactics of what to do, how to do it, and why to do it. It is in this sense that we present the work proposals with the theme within the theoretical reference of the equality of differences and interculturality.

The results presented move in the direction of alternatives to work with teachers, in the continuous training of teachers, and it also presents itself as a practice that can be implemented in the daily life of schools in different cultural, ethnic, and social contexts in various countries and cultures.

The implementation and regulation of educational public policies with regard to dialogue with the diversity of peoples, cultures, and identities presents the possibility of building a more egalitarian education where the rights of all children are guaranteed and where they can build meaningful, dialogical, and intercultural learning, whether it is instrumental, emotional, affective, cultural, or group learning.

The continuity, expansion, and struggle of social movements to ensure permanence of such educational policies guarantee to the whole population the right to be respected within the particularities of their culture and the possibility of dialogue within the diversities, warranting the access, permanence, and experience in the educational context of all children.

\section{Notes}

${ }^{1}$ Law no. 10,639/03 was amended by Law no. 11,645/08 of March 10, with the introduction of compulsory teaching of history and culture of indigenous peoples.

2 The reports highlighted in this work include the data from the $\mathrm{PhD}$ thesis in the postgraduate program in education of the Federal University of São Carlos-UFSCar, defended in 2014. Two white and four black public-school teachers participated in the survey. With regard to the data collection technique, the communicative discussion group, based on the communicative methodology, focused on forming of the identity and teaching practice as a possibility for strengthening black identity and valuing diversity in the school context (Constantino, 2014).

${ }^{3}$ The names of the participants are fictitious, and the interviews took place in 2012-2013. 


\section{Nazaré C. \& de Lima C. - Brazilian Educational Policies}

${ }^{4}$ Zumbi dos Palmares has become a symbol of struggle and resistance in Brazilian history for the black population. He was the leader of Quilombo dos Palmares, a fugitive community of escaped slaves, which gained prominence in the history of Brazil, as it persisted for practically the entire 17 th century and reached over 20,000 inhabitants, including Africans and their descendants, and other groups (Haerter, Nunes, \& Cunha, 2013). It is worth noting that Law no. 10,639/03 adds November 20 (considered the day of Zumbi's death) to the school calendar as the Day of Black Conscience (Munanga \& Gomes, 2006).

\section{References}

Almeida, M. A. B., \& Sanchez, L. P. (2017). Implementação da Lei 10.639/2003 - competências, habilidades e pesquisas para a transformação social. Revista Pro-posições, 28(1), 55-80. doi: 10.1590/1980-6248-2015-0141

Brasil. (1996). Lei no 9.394, 20 de dezembro de 1996. Lei das Diretrizes e Bases da Educação Nacional. Estabelece as diretrizes e bases da educação nacional. p.1-28.

Brasil. (1997). Secretaria de Educação Fundamental. Parâmetros

Curriculares Nacionais: introdução aos parâmetros curriculares nacionais. Brasília: MEC/SEF. 126 p.

Brasil. (1988). Constituição da República Federativa do Brasil:

promulgada em 5 de outubro de 1988.

Brasil. (2004). CNE/CP, Resolução 1/2004. Diário Oficial da União, Brasília, 22 de junho de 2004, Seção 1, p.11.

Carvalho, E. J. G. de, \& Faustino, R. C. (2015). O impacto da diversidade cultural nas políticas educacionais: uma crítica às propostas das agências internacionais. Revista HISTEDBR On-Line, 15(61), 110134. doi: 10.20396/rho.v15i61.8640517

Coelho, M. N. (2011). Lembranças de Angola e vivências no Brasil: educação, trabalho e diversidade étnicas e raciais de mulheres angolanas. Holambra, SP: Editora Setembro.

Constantino, F. L. (2010). Comunidades de Aprendizagem: contribuições da perspectiva dialógica para a construção positiva das identidades das crianças negras na escola. Dissertação de Mestrado. São Carlos: UFSCar. 
Constantino, F. L. (2014). Diálogos e tensões: o olhar de professoras negras e brancas sobre a constituição da identidade negra no contexto escolar. Tese de Doutorado. São Carlos: UFSCar.

Cornejo, J. R. E. (2012). Educacão, interculturalidade e cidadania. Educar em Revista, (43), 239-254. doi: 10.1590/S0104-40602012000100016

Elboj Saso. C. \& Oliver Pérez, E. (2003). Comunidades de aprendizaje: Un modelo de educación dialógica en la sociedad del conocimiento.

Revista Interuniversitaria de Formación del Profesorado, 17(3), 91103. Retrieved from: http://www.redalyc.org/pdf/274/27417306.pdf

Elboj, C. S., Puigdellívol, I. A., Soler, M. G. \& Valls, C. (2002).

Comunidades de aprendizaje: transformar la educación. Espanha: Graó.

Flecha, R., Gómez, J. \& Puigvert, L. (2001). Teoría sociológica contemporánea. Barcelona: Paidós.

Freire, P. (2007). Educação como prática da liberdade. 30. ed. São Paulo: Paz e Terra.

Gomes, N. L. (2010). Diversidade étnico-racial, inclusão e equidade na educação brasileira: desafios, políticas e práticas. Congressos IberoLuso-Brasileiros de Política e Administração da Educação de 2010. Retrieved from: http://www.anpae.org.br/iberolusobrasileiro2010/cdrom/94.pdf

Gomes, N. L. \& Jesus, R. E. (2013). As práticas pedagógicas de trabalho com relações étnico-raciais na escola na perspectiva de Lei 10.639/2003: desafios para a política educacional e indagações para a pesquisa. Educar em Revista, (47), 19-33. doi: 10.1590/S010440602013000100003

Gomes, N. L. \& Silva, P. B. G. (2002). O desafio da diversidade. In: Experiências étnico-culturais para a formação de professores. Org. Nilma Lino Gomes \& Petronilha Beatriz Gonçalves e Silva. Belo Horizonte: Autêntica.

Gómez, J., Latorre, A., Sánchez, M. \& Flecha, R. (2006). Metodología Comunicativa crítica. Barcelona: El Roure Editorial.

Gómez, A. G.,\& Díez-Palomar, F. J. (2009). Metodología comunicativa crítica: transformaciones y cambios en el s.XXI. Revista Electrónica Teoría de la Educación. Educación y cultuta en la sociedade de la 
información, 10(3), 103-118. Retrieved from:

https://www.researchgate.net/publication/42377354_Metodologia_co municativa_critica_transformaciones_y_cambios_en_el_S_XXI

Gouvêa, D. M., \& de Lima, F. (2016). Affirmative action: an overview of the history of resistance, struggle and achievements of the black population in the brazilian context. Social and Education History, 5(1), 1-25. doi: 10.17583/hse.2016.1715

Haerter, L., Nunes, G. H. L., \& Cunha, D. T. R. (2013). Refletindo acerca da contribuição da cultura quilombola aos currículos da educação básica brasileira, através da história da presença da história da África e Afro-Brasileira. Identidade, 18(3), 267-278. Retrieved from: http://periodicos.est.edu.br/index.php/identidade/article/view/1175

Marín, J. (2017). Eurocentrismo, el racismo y interculturalidad en el contexto de a globalización. Revista Educação Pública. Cuiabá, 26(62/2), 477-491. doi: 10.29286/rep.v26i62/2.5473

Munanga, K. (1985). Quadro atual das religiões africanas e perspectivas de mudanças. África. Revista do Centro de Estudos Africanos da USP, São Paulo, 1(8), 60-64. doi: 10.11606/issn.2526-303X.v0i8p60-64

Munanga, K., \& Gomes N. L. (2006). O negro no Brasil de hoje. São Paulo: Global. (Coleção para Entender).

Nune, F. G. (2011). Interculturalidade e o papel da escola na atualidade: reflexões a partir do filme Entre os muros da escola. Pro-Posições, 22(3), 13-129.

Plaja Viñas, T. P. (2019). Un paso más en la investigación en trabajo social: aportaciones de la Metodología Comunicativa. International Journal of Roma Studies, 1(2), 144-158. doi: 10.17583/ijrs.2019.4312

Ruiz, A. A. (2014). Interculturalidad: concepto, alcances y derecho. México: Ediciones Mesa Directiva de la Cámara de Diputados. p. 3142.

Silva, A. C. da. (1987) . Projeto de pesquisa estereótipos em relação ao negro no livro didático. Cadernos de Pesquisa. Fundação Carlos Chagas, 63, 96-97.

Silva, D. D. (2015). As relações dialógicas em Paulo Freire: da ação docente à alfabetização. Revista Educação e Linguagens, 4(7), 56-69. Retrieved from: 
http://www.fecilcam.br/revista/index.php/educacaoelinguagens/articl e/view/841

Wainer, J., \& Melguizo, T. (2018). Políticas de inclusão no ensino superior: avaliação do desempenho de alunos baseado no ENADE de 2012 a 2014. Revista Educação e Pesquisa, 44, 1-15. doi: 10.1590/s15179702201612162807

Marciele Nazaré Coelho is the Deputy Director of Academics Affairs in the Department of SSH at the Instituto Superior de Ciências Sociais e Relações Internacionais (CIS). Angola

Francisca de Lima Constantino is a researcher in the Núcleo de Investigação e Ação Social e Educativa (NIASE) at the Universidade Federal de São Carlos. Brazil

Contact address: daaa@ cis-edu.org 